JOURNAL OF AWARENESS

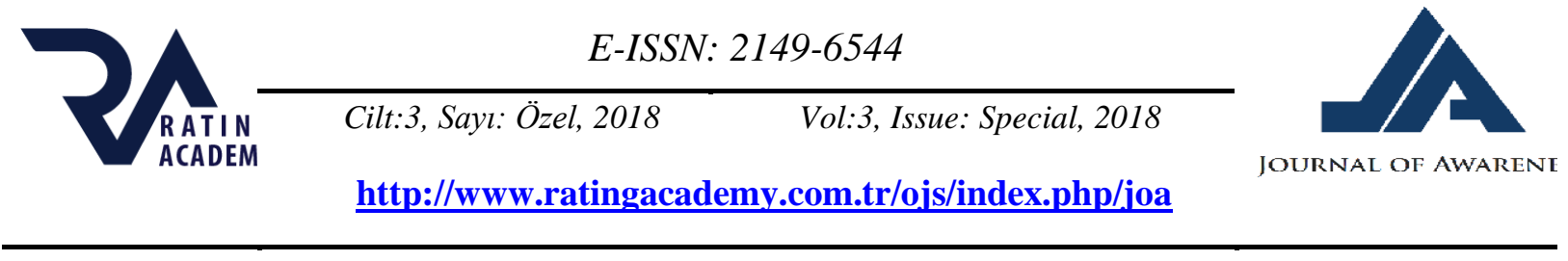

\title{
RHETORIC AND STYLISTICS IN THE FUNCTION OF EFFECTIVE COMMUNICATION*
}

\author{
Albina PAJO \\ Department of Education, Faculty of Education and Philology \\ "Fan S. Noli" University, Korca, Albania \\ E-mail: albino.pajo@yahoo.com
}

\begin{tabular}{l|l}
\hline ARTICLE INFO & \multicolumn{1}{c}{ ABSTRACT } \\
\hline $\begin{array}{l}\text { Keywords: } \\
\text { stylistics, rhetoric, } \\
\text { communication, style, } \\
\text { written expressiveness }\end{array}$ & $\begin{array}{l}\text { Generally speaking there are two basic considerations related to the definitions } \\
\text { given to the word style. } \\
\text { Firstly, the term style is used as an evaluation indicator, thus it is commonly used } \\
\text { in syntagmatic relations such as; explicit style, fluent style, energetic style, } \\
\text { plethoric style, dynamic style etc. Based on different and abundant uses of this } \\
\text { word, sometimes there is a call for a perfect replacement with the word rhetoric. } \\
\text { Secondly, the style is always regarded as a reflection of an author's individuality } \\
\text { and the term rhetoric is associated with the concept ethos, revealing the author's } \\
\text { character. } \\
\text { DOI: }\end{array} \quad \begin{array}{l}\text { Stylistics analyses human language as namely related to communication, } \\
\text { individual and social requirements, its actual functional usage, practical and vivid } \\
\text { more than an abstraction. It also exploits language usage as a second } \\
\text { organization construction. While rhetoric provides necessary and obligatory } \\
\text { devices for approach which would indispensably generate qualitative literary } \\
\text { works, contemporary stylistics aims at describing relevant devices and } \\
\text { approaches of linguistics expression which are considered as necessary } \\
\text { properties for specific works. Both rhetoric and stylistics, using language } \\
\text { properties as fundamental code, contribute at shaping effective communication } \\
\text { giving individual nuances and stylistic values. The aim of this paper is to analyze } \\
\text { issues related to strategy, style, written expressiveness, ambiguity, as well as to } \\
\text { display the similarities and differences between these linguistics disciplines. }\end{array}$ \\
\hline
\end{tabular}

\section{INTRODUCTION}

Rhetoric represents a field which is highly connected to other branches of lore like: communication, dialectics, semiotics, stylistics, esthetic, poetics etc. Rhetoric is linked to all these disciplines by the choice of "the beautiful and purposeful word", the correct grammatical and literal expression which informs, persuades, is favored and could be learnt by means of some specific techniques or can be taught, by strengthening in this way the bases of a discipline as old as new, with practical communicative values.

The strands of the interweaving between rhetoric and stylistics can be found since the antiquity. The western philosophers contribute to Ermogen the authorship of a summery with five books: "Practicum" "Abound the findings" "About the attitude" "About the ideas" "About the flairs", from which, only the third and the forth volume are considered as original, his own work, while the others are studies based on similar writings (Kennedy, 1994). 
In the volume "About the ideas" (Koukoura, 2011: 116) he presents for the first time the seven forms of the style:

The clarity, which besides style is a virtue which should accompany prose and poetry, in order to let them be understandable. He thinks that the clarity is not connected just to clearness, but even to insight.

The value and the importance of the word which require more experience. After possessing the clarity, the rhetorician leads the audience with pathos in order to enterprise positive and negative actions by means of a perfect eloquence.

The alacrity (studying) which is connected to phrase construction, sentence rhythm and rethorical figures that sound agrreably.

The agility which is mainly used in poetry, by choosing suitable rhetorical figures. The poets and rhetoricians try to give life to their work, by making it fluent as the water of a river.

Ethos (the character) which is linked to the personality of the author and his own aim, in order to evoke a specific feeling to the audience.

The idea of the truth which means using properly the rhetorical figures, short sentences with the proper rhythm, in order to convey the message by avoiding a an esthetic conclusion loaded with rhetorical figures.

The mastery refers to the usage of all possible linguistic tools in order to achieve wonderful rhetorical results.

We can say that Ermogen advices the interweaving of the ideas which are expressed by sentences with relevant meaning and using rhetorical figures which are linked to the linguistic form and content in order to achieve stylistic conclusions. In the antiquity, the entirety of the particularities of the style was a specific object of study. By being transmitted from the Antiquity to the Mediaeval period and by being renewed in the era of Classicism, the rhetoric constituted the stylistic, and also the science of expression and the science of literature as far as it was possible to premeditate in that period. So, if I the Antiquity the rhetoric had a specific ethical, political and literary function, in the following centuries it was focused on the style which tended to determine in details an entirety of stylistically forms (metaphors, metonymy, antithesis, allegory etc) and very solid norms that every person who had intention to learn the art of "beautiful writing" and "beautiful speaking" had to obey.

\section{THE COMPARISON BETWEEN THE DEFINITIONS OF THESE DISCIPLINES}

Let us try at first to make an approach towards the definition of these two linguistic fields: According to "The Dictionary of Oxford on Phraseology and Fables" : The rhetoric is the art of persuasive and effective speaking, especially by making use of word figures and other composing techniques; the purposeful language in order to have a persuasive and impressive effect on the audience (Knowles, 2001).

Whereas, according to Xhevat Lloshi (2005: 9) the stylistics regards the language as connected to communication, to social and individual needs, to its functioning in a real, practical, vivid usage rather than as an abstraction. It also studies the usage of language and its variability form a secondary organism perspective. The stylistics traces the features and attitudes of the tools and of the linguistic constructions in this organism in order to make communication as effective as possible and the other complementary requests, adapted to the aim of the lecturer and to the social and cultural tradition. After all, making use of the word figures and other composing techniques or rather saying the secondary organism is an object of 
study for both these fields, and the impressive effect seems to be their common aim while what distinguishes them is the persuasive effect.

\section{A COMPARATIVE AND HITORICAL OVERVIEW ON THE TERMS:}

The term stylistics is used two centuries ago. The stylistics substituted elocution in the old rhetoric, after the work of Charl Balise (1909) on the French stylistic, a discipline which was spread in Europe as a new branch of linguistics. So, the renewed rhetoric includes more the aspects of implemented stylistic (Lloshi, 2005: 14). In this way was created a limited concept for the style. In fact, the style, in this perception was not the private and individual code, capable to create new messages, but it was an imitation, a manner or a habit, while rhetoric was transformed into a fund of dead, chosen, coded forms of the examples which had to be taken as a model (Ballhysa \& Boçi , 2002: 147).

In the everyday usage are spread two main perspectives of the style. On the one hand, the word style is used as an indicator of quality, for this reason it is accompanied with an epithet: clear style, fluent style, energetic style, swollen style, dynamic style etc. and precisely here, the term style can be easily substituted with the term rhetoric. On the other hand, the style is seen as presentation of the individuality of the author where it is noticed again the rhetoric with the concept of ethos, which is highly connected to the character of the author. Stylistics, regards the language as connected to communication, to the social and individual needs, to its functioning during its real, practical, vivid usage, rather than an abstraction. It also studies the usage of the language and its variability from a secondary organism perspective.

According Lloshi (2005:9) the stylistics notices which are the characteristics and the attitude of the tools and the linguistic constructions in this organism in order to make the communication as effective as possible and the other complementary requests adapted to the aim of the lecturer and to the social and cultural tradition.

The study of the rhetoric takes a special place in the literary criticism because it is impossible to judge the style of an author if we do not take in consideration his/her idea for the style (Guiraud, 1997: 24)

One of the great differences between stylistics of modern criticism and traditional rhetoric relates to the fact that modern critics are interested in how these various elements intertwine to produce the only effects of poetry. (Krasniqi, 2013). So, the old rhetoric provides the obligatory tools of access, whose function would bring valuable literary works, while the contemporary stylistics tries to describe the tools and the approaches of the linguistic expression which are a characteristic for specific works. The first one studies the figures as tools of literary expression, as absolute tools of literary expression, which are good on their own, and when are used they bring artistic values. The second, values the function of specific figures in a literary work, as relative tools by means of which the literary expression is realized.

\section{OTHER ISSUES OF THIS APPROACHABLE REVIEW:}

The strategy and the style, (Kane, 1988/2010) in the work "How to write in Albanian", are important considerations of writing in rhetoric. Related to them, he is expressed: "The style is the amount of all the choices of words, sentences and paragraphs... the style is not a superficial decoration, as a tinfoil layer by means of which we can illustrate the main ideas, it is the deep core and not the superficial view of a short part". Also it is affirmed that exist a parallelism between the writing habit that are treated as an issue of growth of expression in the period (there) and graphematics that is seen as a stylistic issue because it is the implementation of the orthography norm that gives to words a writing appearance, a "face", where the perception of the view takes value, so the difference of orthography convey emotional reactions (Lloshi, 2005). 
In this furrow, it is interesting the fact that the same author uses for illustration the same example to refer to the writing expresion and also the graphematics is a matter of style (Lloshi, 2005: 11): "He tried to persuade himself that this was his destiny. HIS DESTINY... It was something unavoidable”.

As an analogue case we can mention this example:

-According to indasian philosophy Ajur Veda, the WORLD is not what we experienceby means of our five senses, but is the way we interprete it in our mind (Dema, 2012: 156)

- If he had not gone out since in the morning, in the Sold Consciousness square, he would still be selling hazelnuts, still be selling... he would sell sky, and sea, and people, and colours, and birds, and San Maria, and the Chief of the Police, and the carabinieri.. (Marko, 1999).

Also, it is mentioned even the lack of the stylistics refering to punctuation marks, or

"zero speech", which refers to the disappearance of the bounderies between direct and reported speech, which consists of style and rhetoric in the same time (Kane, 1988/2010: 659). For example:

-One day in the morning he woke me up and told me to get prepared. Where should I go, I told him. Depart fot Albania, said he. We have allowed a Greek boat together with the Greek Conuslor to leave the harbour, go even you with them. I want to take the remains of my father I said to him, I can not leave empty-handed in the village. Go since it is not too late he said to me. The harbour will be closed and I can not shelter you anymore, because I have to go out and adjust some issues and I do not know if I am coming back anymore (Blushi, 2008: 77).

-This is our fear, said he. We need to celebrate longer the indipendence of Serbia, but even from Albania. We are scared from Albania, said he. By being united we will loose. In fact, he said something that I have begun to feel when I go to Kosovo: the need of the population and of those who lead them to feel Gods in their country. It is an understandable feeling if we take in consideration the history of Kososvo. This is not a feeling that can be reproved, but it should be understood. And explained. In order to find his effect on the future of Albania in general (Blushi, 2014: 55-56).

Therefore, as for the stylisitcs, even for rhetoric, the writing variants and their organisations are of the same importance refering to the expresion, because the writing contains traces of the history of the linguistic usage, which are a value too. Even ambiguity, becomes a matter of word choice in rhetoric. When the author does it on purpose, we have a stylistic profit, usually for humour (ibid.).

- How many heads cost one third of a duck here in Trokth?

- Four sir, but we will bestow even our heads (Xoxe, 1980)

In this case the question is done with the meaning "how many pieces-as a unit of counting", while in the answer the word is used in its first meaning "the upper part of the human body, and the author leaves the equivoc word for irony.

\section{RHETORIC AND COMMUNICATION}

Rhetoric is the first field of knowledge, that from one hand has systematically put under question the language as a mean of communication and on the other hand has proposed systematical techniques in order to make more productive the communicative act. Today this word in the everyday language has even a negative connotation, when we want to identify an empty and emphatic speaking, and also the tendency to manipulate. 
This derivative meaning should not make us forget that rhetoric for a long period of time has suffered the scorn of culture and as a specific discipline continues to affect deeply the relationship between the people (Barthes, 2008).

Rhetoricians, since in the antiquity, have presented the canotical sequence of the pieces, that a direct speech should contain, namely the standard of introduction which is considered more favorable. If we want our argument to be important, we should create it with four parts: the introduction, that notifies the subject and tries to raise the audience's interest; the confession that represents in an objective manner the real facts; the statement, that is the moment of discussion and the proves and, ate last, the closure that makes a summery and gives the conclusions of the speech (Baylon \& Mignot, 2003) .

This, definitely is a preentation, that continues to have a big success even today. The reason is that the rhetoricians, by means of the requests for a plan, formed the natural sequence of the interpersonal communication (Gusdorf, 1952)

Therefore, rhetoric, if is understood properly, is a wonderful reinforcing of the persuasive possibilities, an inner attribute of the language and, in fact, it is constantly in the "linguistic strategies".

Consequently, the actual study of the linguistic strategies follows the direct route of the traditional rhetoric, which evaluates "the defining language", according to which, should be socially adapted since in the beginning, in order to fulfill its primary function which is definitely the communication.

Especially the confession and the assertion lead to the two main patterns of the communication: the fact transmission (of the content) and the meaning exchange that is provided (the relationship).

Roland Barthes in his book "La retorica antica" constructs this postulate in order to express the connection between communication and rhetoric (Barthes, 2000)

"There always exists a base level, a clear foundation of the communicative status, that provides the processing of a difficult expression, by widening or narrowing it in that way that the conclusion might be far from the original", which means that the rhetoric is capable to process the speech or the writing, in order to make communication more effective.

According Barthes (2000:70) the effect of rhetoric in communication can be analyzed by using this relationship postulate between them: "One of the main efforts of a speech is to be meaningful (communication-my note) and to give to the soul the possibility to form a more developed idea than the one that it can express (rhetoric-my note)".

\section{CONCLUSIONS}

Rhetoric and stylistics are fields which interact with each other. By utulizing the figures of speech and the other composing techniques or differently saying the secondary organisation is an object of study for both fields, impressive effect in this way seems to be the common aim, and what distinguishes them is the persuasive effect.

Rhetoric is an amazing reinforcement of the persuasive possibilities, an inner quality of the language and in fact, it is used constantly in the "linguistic strategies".

The actual study of the linguistic strategies follows the direct route of the traditional rhetoric, which evaluates "the defining language", according to which, should be socially adapted since in the beginning, in order to fulfill its primary function which is definitely the communication. 
The confession and the assertion lead to the two main patterns of the communication: the fact transmission (of the content) and the meaning exchange that is provided (the relationship).

In its wider meaning "style" means the amount of all the choices that the author makes on the words, sequence and their organization; in another narrower meaning, the word "style" can denote a specific type of writing that is a feature of a person or a characteristic for a group or profession " "Kadare style", "academic style". What should be emphasized is that there is not just a single style, an ideal way of writing that should be aimed by everyone. The style includes many different ways of writing, each of them suitable for some aims and less suitable for some others, because style itself is an idle concept, with infinite variations.

In conclusion, we can say that, since the style is the person himself/herself and every text denotes its style, literary analyses require the expression of this individuality, which is presented with:

-The figurative character, which searches the emotion by using expression tools that refer not only to the mind but also to the feelings (rhetoric).

-The rhythmical character, with the tools which allow to touch the literary language norms and the poetical freedoms linked to them (stylistics).

\section{BIBLIOGRAPHY}

BALLHYSA, ABDULLA \& BOÇI, LUÇIANO. (2002) Edukim gjuhësor, Tiranë: Shtëpia e Librit Universitar.

BARTHES, ROLAND. (2000) La retorica antica, Roma: Bompiani.

BARTHES, ROLAND. (2008) Aventura semiologjike, Pejë, Kosovë: Dukagjini.

BAYLON, CHRISTIAN. \& MIGNOT, XAVIER. (2003) Komunikimi, $3^{\text {rd }}$ edition, Shkup: Logos-A.

BLUSHI, BEN. (2008) Të jetosh në ishull, Tiranë: Botimet Toena.

BLUSHI, BEN. (2014) Hëna e Shqipërisë, Tiranë: UET Press.

DEMA, ADEM. ( 2012) Dashuria kuantike e Filanit, Prishtinë : LSHK.

GUIRAUD, PIERRE. (1997) Stilistika, Prishtinë: Fjala e Re.

GUSDORF, GEORGES. (1952) La parole, $1^{\text {st }}$ edition, Paris: Paris: Presses universitaires de France.

KANE, S. THOMAS. (1988/2010) The new Oxford guide to writing (Si të shkruajmë shqip), Tiranë: CDE.

KENNEDY, GEORGE. A. (1994) A new history of classical rhetoric and Greek rhetoric under Christian emperors, Princeton, New Jersey: Princeton University press.

KNOWLES, ELISABETH. (2001) The Oxford Dictionary of Phrase and Fable, Oxford: Oxford University Press, Incorporated, Available: http://www.encyclopedia.com/doc/1O214-rhetoric.html.

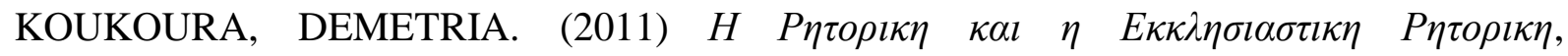
ПOYPNAPAE.

KRASNIQI, GAZMEND. (2013) gazetashqip.com , 8 May, [Online], Available: http://gazetashqip.com/lajme/2013/05/08/stilistika-vs-retorika/ [8 Dec 2018].

LLOSHI, XHEVAT. (2005) Stilistika e gjuhës shqipe dhe pragmatika, Tiranë: Albas.

MARKO, PETRO. (1999) Nata e Ustikës, Tiranë: Mësonjëtorja.

XOXE, JAKOV. (1980) Lumi i vdekur, Tiranë: Shtëpia botuese "Naim Frashëri“. 